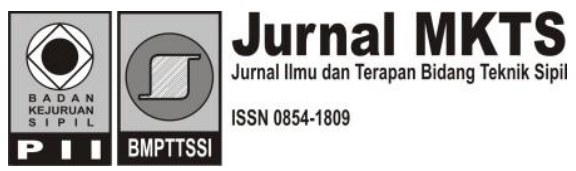

\title{
Aplikasi Manajemen Risiko pada Pembangunan Sistem Penyediaan Air Minum (SPAM) Regional Jawa Tengah (Studi Kasus pada Pembangunan Jaringan Transmisi SPAM Regional Bregas)
}

\author{
Hernoni Septiani \\ Balai Besar Wilayah Sungai Pemali Juana \\ Jl. Brigjen S Sudiarto no 375 Semarang, Indonesia \\ E-mail: hernoniseptiani@gmail.com
}

\section{Agung Wibowo}

Jurusan Teknik Sipil, Fakultas Teknik, Universitas Diponegoro

Jl. Prof. Soedarto, SH, Kampus Undip Tembalang, Semarang, Indonesia 50275

E-mail: agungwibowo360@gmail.com

\section{Syafrudin}

Jurusan Teknik Sipil, Fakultas Teknik, Universitas Diponegoro

Jl. Prof. Soedarto, SH, Kampus Undip Tembalang, Semarang, Indonesia 50275

Email: udin_syaf@yahoo.com

\begin{abstract}
The increasing need for drinking water and undistributed raw water source needs solution with SPAM, Central Java Region. One of it is SPAM Bregas Region which the service locations are in Brebes Districts, Tegal City, and Tegal District. In the process of the transmission network development, there come some risks that hamper so that it needs for further research. This research aims to identify risks, analyze the amount of risk probability and give policy recommendations. The responden of study are government agencies as providers the transmission pipelines development projects of Bregas Regional SPAM, also the supervision consultants and contractors as a service providers. The method used is to spread the questionnaire to each stakeholder for structuring the risk of using RBS (Risk Breakdown Structure) and multiplying the value of the impact and frequency to obtain the value of the level of risk for each risk factor. The results showed the risks that happened in transmission network development in Bregas Regional SPAM are different from each stakeholder. Risks from perception of the supervising consultant $21.95 \%$ is accepted, $18.29 \%$ mitigated, and $59.76 \%$ avoided. Risk from owner perseption $32.93 \%$ is accepted, $23.17 \%$ mitigated, and $43.90 \%$ avoided. Rizks from contractor perseption $23.17 \%$ is accepted, 29.27 mitigated, and $47.56 \%$ avoided. Overall stakeholder's biggest risk is land acquisition.
\end{abstract}

Keywords: Regional's SPAM, Risk, Risk Breakdown Structure (RBS).

\begin{abstract}
Abstrak
Meningkatnya kebutuhan air minum serta tidak meratanya sumber air baku membutuhkan solusi bersama dalam wadah SPAM Regional di Jawa Tengah. Salah satunya adalah SPAM Regional Bregas dengan lokasi pelayanan Kabupaten Brebes, Kota Tegal dan Kabupaten Tegal. Pada pelaksanaan pembangunan jaringan transmisi muncul berbagai risiko yang menghambat sehingga perlu adanya penelitian lebih lanjut. Penelitian ini bertujuan untuk mengidentifikasi risiko, menganalisa besaran probabilitas dan dampak risiko dan memberikan rekomendasi kebijakan. Responden penelitian ini adalah dari instansi pemerintah selaku penyelenggara proyek pembangunan jaringan transmisi SPAM Regional Bregas, serta konsultan supervisi dan kontraktor sebagai penyedia jasa. Metode yang digunakan dengan menyebar kuesioner pada masingmasing stakeholder untuk melakukan strukturisasi risiko menggunakan metode RBS (Risk Breakdown Structure) dan mengalikan nilai dampak dan frekuensi untuk mendapatkan nilai tingkat risiko pada tiap faktor risiko. Hasil analisis tersebut, dianalisa lebih lanjut berdasarkan pengalaman empiris dari para
\end{abstract}


stakeholders untuk mengetahui tindakannya dalam mengatasi risiko. Hasil penelitian menunjukan bahwa risiko yang terjadi pada pekerjaan pembangunan Jaringan Transmisi Kawasan Bregas berbeda-beda bila dilihat dari masing masing stakeholder. Risiko dari persepsi konsultan supervisi 21,95\% diterima, 18,29\% dimitigasi, dan 59,76\% dihindari. Risiko dari persepsi owner 32,93\% diterima, 23,17\% dimitigasi, dan 43,90\% dihindari. Risiko dari persepsi kontraktor 23,17\% diterima, 29,27\% dimitigasi, dan 47,56\% dihindari. Risiko terbesar menurut ketiganya ialah pembebasan lahan.

Kata-kata Kunci: SPAM regional, Risiko, Risk Breakdown Structure (RBS).

\section{Pendahuluan}

Kawasan Pantura Jawa Tengah merupakan wilayah yang sering mengalami permasalahan ketersediaan air bersih khususnya pada musim kemarau, hal ini disebabkan antara lain:

- Peningkatan jumlah penduduk dan aktifitasnya yang mengakibatkan semakin sulitnya mendapatkan pelayanan air minum karena keterbatasan kapasitas

- Terganggunya siklus hidrologi, terbatasnya sumber air baku, jauh dan sulit terjangkau serta berada di wilayah administrasi lain, sehingga tidak mampu diselesaikan oleh secara lokal oleh wilayah (kabupaten atau kota) yang membutuhkan air tersebut.

- Biaya pengolahan air yang cukup mahal sedangkan kemampuan masyarakat umumnya masih rendah sehingga tidak mungkin dibebani biaya sarana pengembangan air minum secara keseluruhan.

- Pemerintah kabupaten/kota dan PDAM belum dapat mencukupi atau bahkan tidak mampu melakukan pengembangan sendiri.
- Terbatasnya sumber mata air potensial yang sulit terjangkau dan berada pada wilayah kabupaten lain.

Dalam Penjelasan Peraturan Pemerintah Republik Indonesia No. 16 Tahun 2005 menyatakan bahwa pengembangan SPAM yang merupakan tanggung jawab pemerintah dan pemerintah daerah diselenggarakan dalam rangka mewujudkan kesejahteraan masyarakat dengan menjamin kebutuhan pokok air minum masyarakat yang memenuhi syarat kualitas, syarat kuantitas, dan syarat kontinuitas.

Untuk mengatasi hal tersebut, pemerintah pusat dan daerah melakukan kerjasama dalam hal pengembangan SPAM Regional di Provinsi Jawa Tengah, dengan merencanakan 9 (sembilan) SPAM regional dimana salah satunya adalah SPAM Regional Bregas. Rencana Pengembangan SPAM Regional di Provinsi Jawa Tengah dapat dilihat pada Gambar 1 berikut:

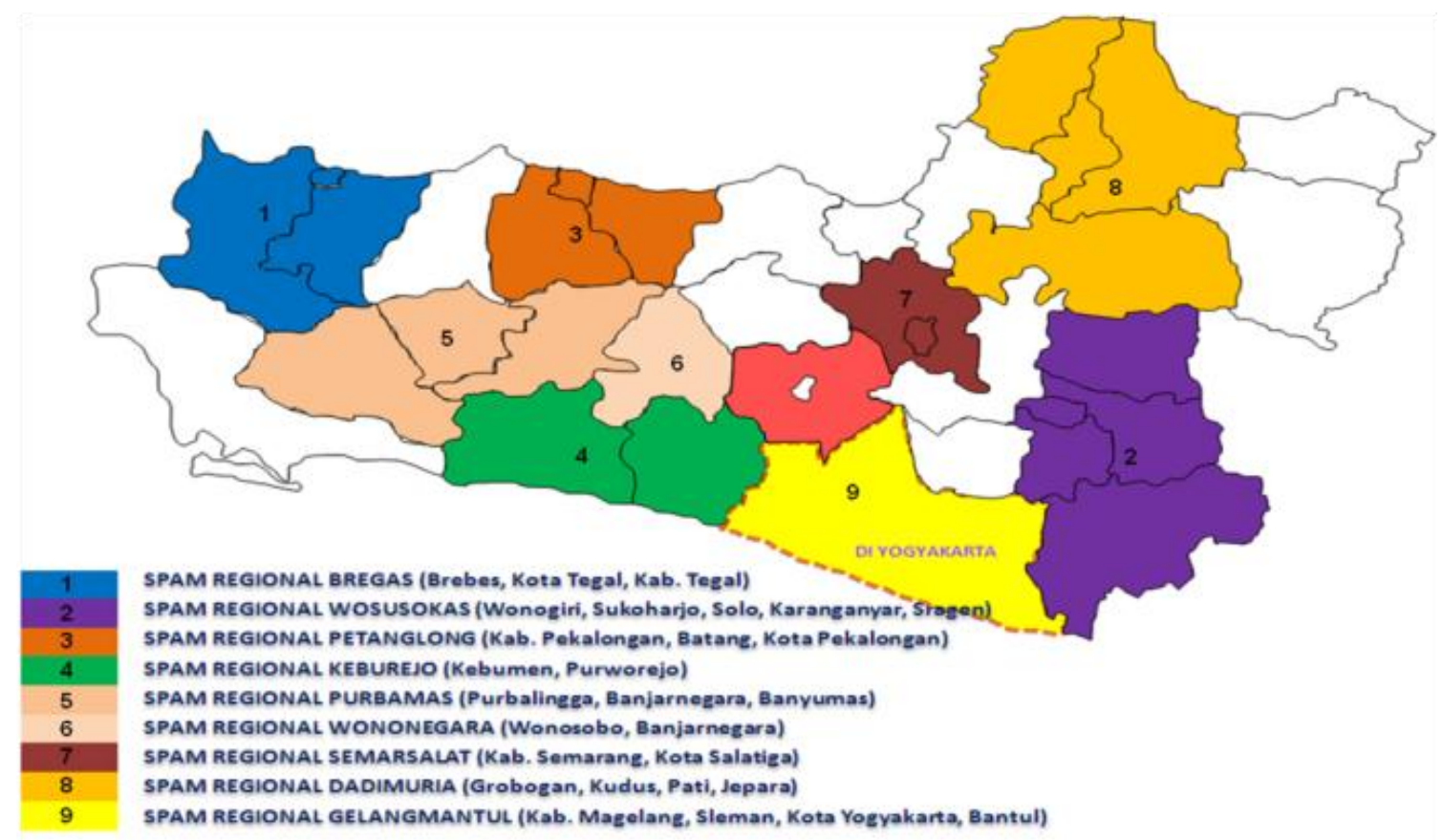

Sumber: Ditjen Cipta Karya Provinsi Jawa Tengah

Gambar 1. Rencana SPAM Regional Provinsi Jawa Tengah 
Tabel 1. Tingkat Risiko (Sonhadji, 2011)

\begin{tabular}{lccccc}
\hline \multirow{2}{*}{ Skala probabilitas } & \multicolumn{5}{c}{ Skala dampak } \\
\cline { 2 - 6 } Sangat besar & Ringan sekali (rs) & Ringan (r) & Sedang (s) & Berat (b) & Ekstrem (e) \\
Besar & $\mathrm{M}$ & $\mathrm{M}$ & $\mathrm{T}$ & $\mathrm{T}$ & $\mathrm{T}$ \\
Sedang & $\mathrm{R}$ & $\mathrm{M}$ & $\mathrm{M}$ & $\mathrm{T}$ & $\mathrm{T}$ \\
Kecil & $\mathrm{R}$ & $\mathrm{M}$ & $\mathrm{M}$ & $\mathrm{T}$ & $\mathrm{T}$ \\
Sangat kecil & $\mathrm{R}$ & $\mathrm{R}$ & $\mathrm{M}$ & $\mathrm{M}$ & $\mathrm{T}$ \\
\hline
\end{tabular}

Keterangan gambar: $\mathrm{R}=$ Risiko rendah; $\mathrm{M}=$ Risiko moderat; $\mathrm{T}=$ Risiko tinggi

Pengertian risiko dalam konteks proyek dapat didefinisikan sebagai suatu penjabaran terhadap konsekuensi yang tidak menguntungkan, secara finansial maupun fisik, sebagai hasil dari keputusan yang diambil atau akibat kondisi lingkungan di lokasi suatu kegiatan (Soemarmo, 2007). Risiko dalam proyek konstruksi merupakan suatu hal yang tidak dapat dihilangkan, tetapi dapat diminimalisir dampaknya.

Skala untuk probabilitas risiko mulai dari nilai 1-5 dengan probabilitas kejadian hampir tidak pernah sampai dengan selalu. Demikian pula untuk dampak risiko diberikan skala dari 1-5 untuk dampak risiko sangat kecil sampai sangat besar (Santoso, 2004). Sedangkan Sonhadji (2011) memberikan skala penilaian untuk probabilitas risiko dari 1-5 dengan probabilitas kejadian sangat kecil sampai sangat besar. Demikian pula untuk dampak risiko diberikan skala dari 1-5 untuk dampak risiko ringan sekali sampai ektrem. Selanjutnya tingkat risiko dikategorikan seperti Tabel 1. Tingkat risiko terdiri dari tiga, yaitu risiko rendah, risiko moderat dan risiko tinggi.

Dari tingkat risiko ini dapat ditentukan risk response planning yang terdiri dari tiga, yaitu diterima untuk risiko rendah, tidak diterima dengan mnitigasi untuk risiko moderat, serta dihindari untuk risiko tinggi.

Dalam PMBOK $3^{\text {rd }}$ edition, 2004, tahapan manajemen risiko terdiri dari enam tahap, yaitu risk management planning, risk identification, qualitative risk analysis, quantitative risk analysis, risk response planning, risk monitoring and control. Risk identification merupakan tahapan di mana risiko diidentifikasi melalui proses brainstorming, sedangkan qualitative risk analysis merupakan tahapan di mana risiko dinilai secara kualitatif dari data proyek terdahulu serta rencana manajemen risiko. Quantitative risk analysis adalah tahapan di mana risiko dinilai dengan skala. Penilaian secara kuantitatif ini didasarkan pada rumus tingkat kepentingan risiko yaitu frekuensi dikalikan dampak (Zhi, 1995).
Tingkat kepentingan resiko $=$ frekuensi $\times$ dampak .. (1)

dimana:

Frekuensi $=$ probabilitas seringnya risiko tersebut terjadi

Dampak = seberapa besar pengaruh suatu risiko terhadap biaya, mutu, waktu proyek

Sementara itu dalam Nurdiana (2011) bahwa hasil analisis dengan metode RBS risiko terbesar adalah risiko pengadaan lahan yang terlambat dengan tingkat risiko 20, sedangkan dengan metode AHP risiko terbesar adalah risiko pengadaan lahan yang terlambat dengan tingkat risiko 0,0073. Dan dalam Istijono (2014) bahwa penyediaan lahan merupakan faktor penentu untuk kelancaran pembangunan dan hampir tidak ada kegiatan pembangunan yang tidak memerlukan lahan.

Penelitian ini adalah untuk mengkaji faktor risiko pada pelaksanaan pekerjaan Pembangunan Jaringan Transmisi SPAM Regional Kawasan Bregas tahap II (Tuk Suci) sehingga nantinya dapat diminimalisir untuk proyek sejenis di masa yang akan datang, sedangkan tujuannya adalah untuk mengidentifikasi risiko, menganalisis risiko, dan mengetahui respon risiko serta strategi terhadap respon risiko dari para stakeholders yang terlibat pada proyek Pembangunan Jaringan Transmisi Air Baku Sistem Penyediaan Air Minum (SPAM) Regional Bregas, dan memberikan rekomendasi kebijakan sebagai bahan pertimbangan dalam pembangunan SPAM regional berikutnya.

\section{Metode Penelitian}

Data diperoleh dengan mengkombinasikan data primer dan sekunder. Data primer diambil dari kuesioner, wawancara dengan para pihak yang terkait dalam pelaksanaan kegiatan Pembangunan SPAM Regional Bregas, serta dari hasil survey lapangan. Sedangkan data sekunder yaitu data yang diperoleh dari literature yang berkaitan dengan topik studi dan data-data SPAM Regional Bregas. 
Kuesioner dilakukan dalam dua tahapan yaitu:

Tahap pertama dengan sembilan responden yang mewakili 3 stakeholder yaitu masing masing 3 orang responden dari sudut pandang owner, 3 orang responden dari sudut pandang kontraktor, dan 3 orang responden dari sudut pandang konsultan supervisi. Hal ini dilakukan untuk mendapatkan data mengenai variabel risiko yang relevan terhadap proyek Pembangunan Jaringan Transmisi Kawasan Bregas Tahap II (Tuk Suci) dengan mengadopsi tabel variabel risiko dari pedoman Analisis Risiko Investasi Jalan Tol (Pd T-01-2005-B ) oleh Departemen Pekerjaan Umum tahun 2005 yang berkaitan dengan proyek Pembangunan Jaringan Transmisi Bregas pada masa pra pelaksanaan dan masa pelaksanaan pekerjaan, ditambah masukan dari hasil wawancara dengan para pihak yang berkompenten.

Data tersebut diolah menggunakan skala Guttman, dengan dua interval, yaitu relevan dan tidak relevan. Skala Guttman dibuat dalam daftar checklist variabel risiko yang ada, untuk jawaban positif relevan diberi skor 1; sedangkan untuk jawaban negatif tidak relevan diberi skor 0 . Jika satu responden saja yang menyatakan risiko tersebut relevan, maka risiko tersebut dinyatakan relevan atau variabel risiko tersebut mungkin dapat terjadi pada proyek.

Tahap kedua atau tahap analisa risiko dimulai dengan melakukan survey kedua untuk mendapatkan nilai probabilitas dan dampak dari setiap variabel yang relevan sebelumnya. Sama halnya dengan survey Pendahuluan, pada survey ini juga dilakukan kusioner dan wawancara (faceto-face interview) dengan 16 (enam belas) responden dari tiga pihak tersebut. Pada tahap ini dalam pembobotan probabilitas dan dampak menggunakan skala Linkert, yaitu skala yang dapat dipergunakan untuk mengukur sikap, pendapat, dan persepsi seseorang atau sekelompok orang mengenai suatu gejala atau fenomena untuk dampak risiko diberikan skala dari 1-5.

Selanjutnya tingkat risiko dikategorikan menjadi tiga tingkatan, yaitu risiko rendah, risiko moderat dan risiko tinggi. Dari tingkat risiko ini dapat ditentukan risk response planning yang terdiri dari tiga, yaitu diterima untuk risiko rendah, tidak diterima dengan mitigasi untuk risiko moderat, serta dihindari untuk risiko tinggi.

\section{Analisis Data dan Pembahasan}

Terdapat 8 (delapan) kelompok risiko yaitu kelompok risiko desain dan studi, kelompok risiko pembebasan lahan dan kelompok risiko pembangunan/konstrusi, kelompok risiko perijinan/pra konstruksi, kelompok risiko pembiayaan, kelompok risiko force majeur dan kelompok risiko politik dan sosial, serta kelompok risiko peralatan, dengan 82 (delapan puluh dua) faktor risiko yang dianalisa sebagai berikut :

\section{Perijinan/pra konstruksi}

1) Proses tender yang kurang transparan sehingga dapat menimbulkan risiko kegagalan

2) Dokumen kontrak yang tidak mengatur secara detil tentang penanggulangan risiko investasi

3) Gambar saat tender tidak lengkap

4) Tidak adanya persyaratan analisa risiko dalam dokumen penawaran

5) Keterlambatan proses pelelangan karena menunggu persetujuan multi years

6) Pelelangan tidak sesuai aturan

7) Pelelangan yang tidak mengharuskan penyedia jasa meninjau lokasi dalam menawar

8) Keterbatasan kewenangan dalam kesepakatan bersama maupun perjanjian kerja sama antar instansi terkait

9) Adanya instansi yang tidak masuk dalam perjanjian kesepakatan bersama (MOU)

10)Klausul-klausul kontrak yang kurang lengkap

\section{Desain dan studi}

1) Data yang digunakan dalam studi kelayakan kurang akurat sehingga berpotensi menimbulkan kesalahan estimasi

2) Desain yang tidak matang, kondisi sebenarnya yang belum diketahui secara pasti atau belum adanya penyelidikan tanah pada lokasi yang labil, elevasi bangunan, dan data existing lainnya

3) Perencanaan yang kurang tepat sehingga berpotensi menimbulkan risiko perubahan rencana yang telah dibuat

4) Pemahaman terhadap desain berpengaruh terhadap kinerja proyek

5) Desain tidak sesuai dengan lingkup kerja

6) Detail BOQ yang tidak lengkap

7) Perencanaan yang tidak mempertimbangkan antara kebutuhan terhadap ketersediaan air

8) Perubahan jalur pipa terhadap perubahan desain

\section{Pembebasan lahan}

1) Lahan yang dibutuhkan untuk pembangunan pekerjaan tidak sepenuhnya dapat disediakan oleh pemerintah sehingga dapat mengganggu realisasi rencana yang ada

2) Proses ganti rugi sulit dilaksanakan dan harga kompensasi yang terjadi di atas perkiraan anggaran yang disediakan

3) Proses pembebasan dan ganti rugi lahan yang lamban 
4) Adanya penolakan warga terhadap pembebasan lahan berpengaruh pada kinerja proyek

5) Banyaknya calo atau perantara dalam pembebasan tanah menimbulkan ketidakpastian harga dan harga pembebasan tanah menjadi lebih mahal

6) Belum adanya kepastian kebutuhan lahan yang harus dibebaskan

7) Proses pembebasan lahan yang berbenturan dengan instansi lain (Kementerian Kehutanan)

8) Lahan yang digunakan berbenturan dengan lahan dari instansi lain (misal: Bina Marga, PT. KAI, Irigasi dll)

\section{Pembiayaan}

1) Risiko yang muncul akibat ketidakpastian dalam hal kontinuitas sumber dana pembiayaan (tahun berikutnya) sehingga dapat menimbulkan risiko keterlambatan dan biaya overhead

2) Kenaikan harga material selama masa pelaksanaan

3) Kenaikan harga lahan yang dibebaskan saat pelaksanaan pekerjaan berlangsung

4) Terjadi pekerjaan tambah dengan harga timpang

5) Terjadi keterlambatan jadwal proyek berpengaruh pada biaya proyek

6) Adanya ketidakpastian dalam tingkat suku bunga pinjaman yang harus dibayarkan selama masa konstruksi

7) Kesalahan dalam mengestimasi dan merencanakan anggaran biaya untuk material

8) Meningkatnya biaya untuk faktor-faktor nonteknis

9) Perubahan kondisi perekonomian negara dan kebijakan pemerintah terhadap keuangan

\section{Pembangunan/konstruksi}

1) Kondisi lapangan yang sulit dan tidak terduga, sehingga membutuhkan biaya yang lebih besar

2) Kondisi cuaca yang kurang baik sehingga mengganggu kelancaran pelaksanaan pekerjaan

3) Ketidakpastian dalam ketersediaan material yang dibutuhkan untuk pembangunan, sehingga menimbulkan risiko peningkatan biaya

4) Kondisi keamanan di lokasi proyek yang dapat menimbulkan risiko kehilangan material atau logistik proyek

5) Kualitas pelaksanaan yang kurang baik sehingga tidak dapat memenuhi kriteria spesifikasi

6) Manajemen pelaksanaan proyek yang kurang baik sehingga menimbulkan inefisiensi dalam pelaksanaan pembangunan
7) Kemungkinan terjadinya mogok akibat ketidakpuasan pekerja proyek sehingga dapat menimbulkan potensi keterlambatan

8) Penyusunan jadwal pelaksanaan pekerjaan yang kurang baik sehingga menimbulkan risiko keterlambatan

9) Estimasi biaya konstruksi yang kurang akurat sehingga menimbulkan tambahan biaya yang tidak terduga

10) Kemungkinan terjadinya peningkatan hargaharga material akibat inflasi dan eskalasi biaya

11) Adanya pekerja atau pelaksana yang tidak jujur sehingga menimbulkan risiko kerugian akibat kehilangan atau penambahan biaya

12) Timbulnya kemacetan di sekitar lokasi proyek akibat adanya proyek

13) Metode pelaksanaan yang tidak / kurang tepat

14) Konflik internal dalam jajaran manajemen proyek

15) Adanya oknum-oknum yang tidak bertanggungjawab yang mengganggu pelaksanaan proyek (misal: pemerasan dll)

16) Kesalahan dalam memprediksi kondisi lapangan, cuaca dan kejadian yang akan datang

17) Pembuatan jadwal pengiriman material yang kurang akurat dan teliti

18) Kesulitan dalam pengadaan material (lokasi sulit dijangkau dan jauh dari jalan besar)

19) Tingginya tingkat kerusakan material selama proses penyimpanan

20) Kesalahan dalam menerapkan standar metode konstruksi untuk melakukan suatu pekerjaan

21) Kesalahan penerapan gambar kerja lapangan

22) Tidak mengikuti prosedur pentahapan kerja

23) Kualitas pekerjaan pemasangan tidak sesuai spesifikasi

24) Pemborosan pemakaian material di lokasi

25) Penggunaan dan pemotongan bentuk material yang tidak efisien

26) Handling material yang kurang hati - hati

27) Perbaikan pekerjaan / rework

28) Terjadinya percepatan jadwal

29) Sedikitnya penyelenggaraan rapat-rapat koordinasi di lapangan

30) Administrasi dan sistem dokumentasi penyedia jasa yang lemah

31) Sistem evaluasi dan pengambilan keputusan yang rendah

32) Rendahnya pengawasan material di lokasi proyek

\section{Peralatan}

1) Adanya peralatan/bahan yang harus diimpor sehingga menimbulkan ketidakpastian mengenai pengadaan alat yang dibutuhkan

2) Kinerja peralatan yang digunakan kurang baik atau produktifitasnya tidak sesuai dengan yang 
direncanakan sehingga berpotensi mengakibatkan kerugian atau keterlambatan.

3) Kebutuhan akan teknologi yang memadahi untuk pekerjaan yang kompleks

4) Kerusakan peralatan (alat berat) mengakibatkan keterlambatan

5) Kurangnya peralatan dalam mendukung pekerjaan di lapangan

\section{Risiko force majeur}

1) Terjadinya bencana alam di daerah lokasi proyek (seperti gempa bumi, gunung meletus, tanah longsor, banjir) sehingga mengakibatkan kegagalan atau keterlambatan penyelesaian pekerjaan

2) Terjadinya ketidakstabilan keamanan nasional sehingga berpengaruh terhadap kinerja proyek

3) Adanya demo penolakan masyarakat terhadap pengambilan di mata air

4) Adanya gerakan tanah yang tidak stabil dan tidak diperkirakan sebelumnya

5) terjadinya gejolak politik yang luar biasa sehingga berpotensi terjadinya revolusi yang dapat menghambat penyelesaian proyek yang dilaksanakan

\section{Politik dan sosial}

1) Adanya pergantian pejabat daerah berakibat pada pengambilan keputusan

2) Jadwal pelaksanaan pekerjaan yang bersamaan dengan Pilkada (baik dari tingkat Kepala Desa, Camat ataupun Kepala Daerah) berakibat mundurnya jadwal pelaksanaan

3) Adanya kepercayaan warga terhadap hari hari keramat yang melarang pekerja bekerja pada hari tersebut membuat jadwal pelaksanaan pekerjaan terganggu

4) Kelemahan dalam penyelesaian perselisihan antara pihak-pihak tertentu

5) Koordinasi antar fungsi pada organisasi proyek yang kurang

\section{Analisis risiko dari persepsi konsultan supervisi}

Konsultan supervisi pada proyek ini adalah PT. Yodya Karya (Persero). Hasil survey Pendahuluan terhadap konsultan supervisi mendapatkan 34 faktor risiko yang relevan, yang dilanjutkan dengan tahap kedua analisa risiko.

Menurut pendapat konsultan supervisi dari hasil kuesioner tahap kedua, kelompok risiko yang mempunyai risiko tertinggi adalah kelompok risiko desain dan studi, kelompok risiko pembebasan lahan dan kelompok risiko pembangunan/konstrusi kemudian diikuti kelompok risiko perijinan/pra konstruksi, kelompok risiko pembiayaan, kelompok risiko force majeur dan kelompok risiko politik dan sosial, dengan katagori tingkat risiko tinggi dan respon risiko adalah dihindari, sedangkan kelompok risiko terendah adalah kelompok risiko peralatan dengan katagori tingkat risiko moderat dan respon risiko mitigasi.

\section{Analisis risiko dari persepsi pemilik pekerjaan (owner)}

Pemilik pekerjaan (owner) pada proyek ini adalah Balai Besar Wilayah Sungai Pemali Juana PPK Penyediaan Air Baku. Hasil survey Pendahuluan terhadap pemilik pekerjaan (owner) mendapatkan 46 faktor risiko yang relevan, yang dilanjutkan dengan tahap kedua analisa risiko.

Sedangkan menurut pendapat pemilik pekerjaan (owner) dari hasil kuesioner tahap kedua, kelompok risiko yang mempunyai risiko tertinggi adalah kelompok risiko perijinan/pra konstruksi, dan kelompok risiko pembebasan lahan kemudian diikuti kelompok risiko desain dan studi, kelompok risiko pembangunan/konstrusi, kelompok risiko Pembiayaan, dan kelompok risiko force majeur, dengan katagori tingkat risiko tinggi dan respon risiko adalah dihindari, sedangkan kelompok risiko politik dan sosial, dan kelompok risiko pembiayaan mempunyai katagori tingkat risiko moderat dengan respon risiko mitigasi. Kelompok risiko terendah adalah kelompok risiko peralatan dengan katagori tingkat risiko moderat dan reson risiko mitigasi.

\section{Analisis risiko dari persepsi kontraktor}

Kontraktor pada pekerjaan ini adalah dari PT. Wijaya Karya (Persero). Hasil survey pendahuluan dengan responden kontraktor diperoleh faktor risiko sebanyak 53 variabel yang relevan.

Dan berdasarkan pendapat kontraktor dari hasil kuesioner tahap kedua, kelompok risiko yang mempunyai risiko tertinggi adalah kelompok risiko desain dan studi, kelompok risiko pembebasan lahan dan kelompok risiko pembangunan/konstrusi kemudian diikuti kelompok risiko perijinan/pra konstruksi, kelompok risiko pembiayaan, kelompok risiko force majeur dan kelompok risiko politik dan sosial, dengan katagori tingkat risiko tinggi dan respon risiko adalah dihindari, sedangkan kelompok risiko terendah adalah kelompok risiko peralatan dengan katagori tingkat risiko moderat dan reson risiko mitigasi.

Hasil analisis tingkat risiko yang dilakukan terhadap responden pada stakeholder konsultan supervisi, pemilik pekerjaan (owner) dan kontraktor tidak sama. 
Tabel 2. Respon risiko kelompok konsultan supervisi

\begin{tabular}{clccccc}
\hline No. & \multicolumn{1}{c}{ Risiko } & Probabilitas & Dampak & $\begin{array}{c}\text { Tingkat } \\
\text { risiko }\end{array}$ & $\begin{array}{c}\text { Katagori } \\
\text { tingkat } \\
\text { risiko }\end{array}$ & Respon risiko \\
\hline $\mathbf{1}$ & \multicolumn{1}{c}{$\mathbf{2}$} & $\mathbf{3}$ & $\mathbf{4}$ & $\mathbf{5 = ( 3 \times 4 )}$ & $\mathbf{6}$ & $\mathbf{7}$ \\
\hline $\mathbf{I .}$ & Perijinan/pra konstruksi & & & & & \\
1 & $\begin{array}{l}\text { Gambar saat tender tidak lengkap } \\
2\end{array}$ & 4 & 4 & 16 & tinggi & dihindari \\
3 & $\begin{array}{l}\text { Pelelangan tidak sesuai aturan } \\
\text { Pelelangan yang tidak }\end{array}$ & 2 & 3 & 6 & ringan & diterima \\
& $\begin{array}{l}\text { mengharuskan penyedia jasa } \\
\text { meninjau lokasi dalam menawar }\end{array}$ & 4 & 4 & 16 & tinggi & dihindari \\
\hline
\end{tabular}

Tabel 3. Respon risiko kelompok konsultan owner

\begin{tabular}{|c|c|c|c|c|c|c|}
\hline No. & Risiko & Probabilitas & Dampak & $\begin{array}{c}\text { Tingkat } \\
\text { risiko }\end{array}$ & $\begin{array}{c}\text { Katagori } \\
\text { tingkat } \\
\text { risiko }\end{array}$ & Respon risiko \\
\hline 1 & 2 & 3 & 4 & $5=(3 \times 4)$ & 6 & 7 \\
\hline \multicolumn{7}{|c|}{ I. Perijinan/pra konstruksi } \\
\hline 1 & Gambar saat tender tidak lengkap & 3 & 4 & 12 & moderat & mitigasi \\
\hline 2. & $\begin{array}{l}\text { Tidak adanya persyaratan analisa } \\
\text { risiko dalam dokumen penawaran }\end{array}$ & 3 & 4 & 12 & moderat & mitigasi \\
\hline 3. & $\begin{array}{l}\text { Keterlambatan proses pelelangan } \\
\text { karena menunggu persetujuan } \\
\text { multi years }\end{array}$ & 3 & 5 & 15 & tinggi & dihindari \\
\hline 4. & Pelelangan tidak sesuai aturan & 1 & 3 & 3 & ringan & diterima \\
\hline 5. & $\begin{array}{l}\text { Pelelangan yang tidak } \\
\text { mengharuskan penyedia jasa } \\
\text { meninjau lokasi dalam menawar }\end{array}$ & 5 & 5 & 25 & tinggi & dihindari \\
\hline 6. & $\begin{array}{l}\text { Keterbatasan kewenangan dalam } \\
\text { kesepakatan bersama maupun } \\
\text { perjanjian kerja sama antar } \\
\text { instansi terkait }\end{array}$ & 3 & 4 & 12 & moderat & mitigasi \\
\hline 7. & $\begin{array}{l}\text { Adanya instansi yang tidak masuk } \\
\text { dalam perjanjian kesepakatan } \\
\text { bersama (MOU) }\end{array}$ & 2 & 4 & 8 & ringan & diterima \\
\hline
\end{tabular}

Tabel 4. Respon risiko kelompok kontraktor

\begin{tabular}{|c|c|c|c|c|c|c|}
\hline No. & Risiko & Probabilitas & Dampak & $\begin{array}{c}\text { Tingkat } \\
\text { risiko }\end{array}$ & $\begin{array}{l}\text { Katagori } \\
\text { tingkat } \\
\text { risiko }\end{array}$ & Respon risiko \\
\hline 1 & 2 & 3 & 4 & $5=(3 \times 4)$ & 6 & 7 \\
\hline \multicolumn{7}{|c|}{ Perijinan/pra konstruksi } \\
\hline 1 & Gambar saat tender tidak lengkap & 4 & 5 & 20 & tinggi & dihindari \\
\hline 2 & Pelelangan tidak sesuai aturan & 3 & 4 & 12 & moderat & mitigasi \\
\hline 3 & $\begin{array}{l}\text { Pelelangan yang tidak } \\
\text { mengharuskan penyedia jasa } \\
\text { meninjau lokasi dalam menawar }\end{array}$ & 2 & 4 & 8 & ringan & diterima \\
\hline
\end{tabular}

Perhitungan untuk kategori kelompok risiko perijinan/pra konstruksi disajikan dalam Tabel 2, Tabel 3, Tabel 4.

Hasil analisis dari 8 (delapan) katagori kelompok risiko yang dinilai, memperoleh hasil sebagaimana ditunjukkan pada Tabel 5 .

Pada Tabel 5 tergambarkan bahwa setiap stakeholder mempunyai persepsi yang berbeda beda, walaupun demikian terdapat katagori risiko yang menurut ketiga stakeholder merupakan faktor yang memiliki nilai faktor risiko paling besar yaitu kelompok risiko pembebasan lahan, dan menurut ketiga stakeholder mempunyai persepsi yang sama dalam hal penilaian tingkat risiko terendah yaitu kelompok risiko peralatan, untuk lebih jelasnya dapat dilihat pada diagram spider web pada Gambar 2. 
Tabel 5. Tingkat risiko tertinggi hasil kuesioner menurut para stakeholder

\begin{tabular}{lccc}
\hline \multirow{2}{*}{ Kelompok risiko } & \multicolumn{3}{c}{ Nilai tingkat risiko tertinggi } \\
\cline { 2 - 4 } & Supervisi & Owner & Kontraktor \\
\hline Perijinan/pra & 16 & 25 & 20 \\
konstruksi & & & \\
Desain dan studi & 25 & 20 & 25 \\
Pembebasan lahan & 25 & 25 & 25 \\
Pembiayaan & 20 & 15 & 20 \\
Pembangunan/ & 25 & 20 & 25 \\
konstruksi & & & \\
Peralatan & 16 & 12 & 15 \\
Risiko force majeur & 20 & 20 & 20 \\
Politik dan sosial & 20 & 12 & 16 \\
\hline
\end{tabular}

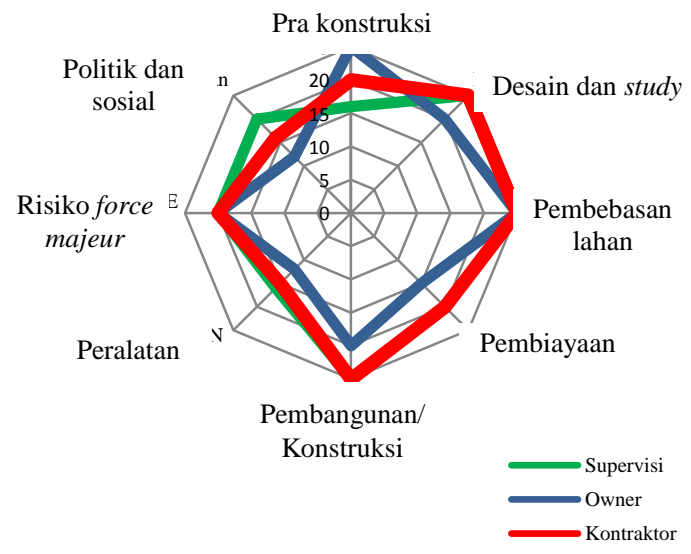

\section{Gambar 2. Spider Web diagram risiko SPAM} Bregas dari para pihak

\section{Tingkat risiko menurut pendapat para stakeholder}

Menurut pendapat konsultan supervisi tingkat risiko terbesar ada pada kelompok risiko desain dan studi dengan nilai 25 yaitu risiko perubahan jalur pipa terhadap perubahan desain, sedangkan pada kelompok risiko pembebasan lahan dengan nilai 25 yaitu risiko proses pembebasan dan ganti rugi lahan yang lamban, risiko banyaknya calo atau perantara dalam pembebasan tanah menimbulkan ketidakpastian harga dan harga pembebasan tanah menjadi lebih mahal, dan risiko proses pembebasan lahan yang berbenturan dengan Instansi lain (Kementerian Kehutanan); serta pada kelompok risiko konstruksi yaitu risiko kesulitan dalam pengadaan material (lokasi sulit dijangkau dan jauh dari jalan besar).

Menurut pendapat owner tingkat risiko terbesar ada pada kelompok risiko perijinan dengan nilai 25 yaitu risiko pelelangan yang tidak mengharuskan penyedia jasa meninjau lokasi dalam menawar; pada kelompok risiko pembebasan lahan dengan nilai 25 yaitu pada risiko lahan yang dibutuhkan untuk pembangunan pekerjaan tidak sepenuhnya dapat disediakan oleh pemerintah sehingga dapat mengganggu realisasi rencana yang ada, risiko proses ganti rugi sulit dilaksanakan dan harga kompensasi yang terjadi di atas perkiraan anggaran yang disediakan, dan risiko Proses pembebasan dan ganti rugi lahan yang lamban.

Menurut pendapat kontraktor tingkat risiko terbesar ada pada kelompok risiko desain dan studi dengan nilai 25 yaitu pada risiko perencanaan yang kurang tepat sehingga berpotensi menimbulkan risiko perubahan rencana yang telah dibuat; sedangkan pada kelompok risiko pembebasan lahan dengan nilai 25 yaitu pada risiko lahan yang dibutuhkan untuk pembangunan pekerjaan tidak sepenuhnya dapat disediakan oleh pemerintah sehingga dapat mengganggu realisasi rencana yang ada, risiko proses ganti rugi sulit dilaksanakan dan harga kompensasi yang terjadi di atas perkiraan anggaran yang disediakan, risiko proses pembebasan dan ganti rugi lahan yang lamban, risiko adanya penolakan warga terhadap pembebasan lahan berpengaruh pada kinerja proyek dan risiko proses pembebasan lahan yang berbenturan dengan Instansi lain (Kementerian Kehutanan), serta pada kelompok risiko konstruksi yaitu pada risiko kondisi lapangan yang sulit dan tidak terduga, sehingga membutuhkan biaya yang lebih besar, dan risiko kondisi cuaca yang kurang baik sehingga mengganggu kelancaran pelaksanaan pekerjaan.

Selanjutnya berdasarkan hasil analisa menghasilkan tingkat risiko, yaitu risiko rendah dengan nilai tingkat risiko $0-10$ dengan risk response planning "diterima", risiko moderat dengan nilai tingkat risiko 11-12 dengan risk response planning "mitigasi" dan risiko tinggi dengan nilai > 12 dengan risk response planning "dihindari".

Respon risiko dari persepsi responden adalah sebagai Tabel 6, Tabel 7, Tabel 8.

Tabel 6. Respon risiko dari persepsi konsultan supervisi

\begin{tabular}{lccc}
\hline $\begin{array}{c}\text { Respon } \\
\text { risiko }\end{array}$ & $\begin{array}{c}\text { Katagori } \\
\text { tingkat } \\
\text { risiko }\end{array}$ & $\begin{array}{c}\text { Jumlah } \\
\text { risiko }\end{array}$ & $\begin{array}{c}\text { Prosentase } \\
\text { risiko(\%) }\end{array}$ \\
\hline Diterima & Ringan & 7 & 20,00 \\
Mitigasi & Moderat & 6 & 17,14 \\
Dihindari & Tinggi & 22 & 62,86 \\
\hline
\end{tabular}

Tabel 7. Respon risiko dari persepsi owner

\begin{tabular}{lccc}
\hline $\begin{array}{c}\text { Respon } \\
\text { risiko }\end{array}$ & $\begin{array}{c}\text { Katagori } \\
\text { tingkat } \\
\text { risiko }\end{array}$ & $\begin{array}{c}\text { Jumlah } \\
\text { risiko }\end{array}$ & $\begin{array}{c}\text { Prosentase } \\
\text { risiko (\%) }\end{array}$ \\
\hline Diterima & Ringan & 13 & 30,23 \\
Mitigasi & Moderat & 11 & 25,58 \\
Dihindari & Tinggi & 19 & 44,19 \\
\hline
\end{tabular}


Tabel 8. Respon risiko dari persepsi kontraktor

\begin{tabular}{cccc}
\hline $\begin{array}{c}\text { Respon } \\
\text { risiko }\end{array}$ & $\begin{array}{c}\text { Katagori } \\
\text { tingkat } \\
\text { risiko }\end{array}$ & $\begin{array}{c}\text { Jumlah } \\
\text { risiko }\end{array}$ & $\begin{array}{c}\text { Prosentase } \\
\text { risiko (\%) }\end{array}$ \\
Diterima & Ringan & 11 & 20,75 \\
Mitigasi & Moderat & 18 & 33,96 \\
Dihindari & Tinggi & 24 & 45,28 \\
\hline
\end{tabular}

\section{Kesimpulan}

Penelitian ini diperoleh beberapa kesimpulan sebagai berikut:

1. Risiko yang terjadi pada pekerjaan Pembangunan Jaringan Transmisi Kawasan Bregas akan berbeda-beda bila dilihat dari masing masing stakeholder. Risiko terbesar menurut persepsi konsultan supervisi adalah kelompok risiko desain dan studi, pembebasan lahan dan kelompok risiko pembangunan / konstruksi. Risiko terbesar menurut persepsi owner atau pemilik pekerjaan adalah kelompok risiko perijinan/prakonstruksi, dan pembebasan lahan. Sedangkan risiko terbesar menurut persepsi kontraktor adalah kelompok risiko desain dan studi, pembebasan lahan dan kelompok risiko pembangunan/konstruksi. Secara keseluruhan stakeholder risiko terbesar ialah pembebasan lahan.

2. Respon risiko dari persepsi para stakeholder diperoleh berdasarkan tingkat risiko dari hasil analisis risiko. Risiko dari persepsi konsultan supervisi sebesar $20,00 \%$ dapat diterima, $17,14 \%$ dimitigasi, dan $62,86 \%$ dihindari. Risiko dari persepsi owner atau pemilik pekerjaan sebesar 30,23\% dapat diterima, $25,58 \%$ dimitigasi, dan $44,19 \%$ dihindari. Risiko dari persepsi kontraktor sebesar $20,75 \%$ dapat diterima, 33,96\% dimitigasi, dan 45,28\% dihindari.

3. Pimpinan instansi pemerintah sebaiknya menerapkan manajemen risiko dengan merinci penetapan konteks, identifikasi risiko, analisis risiko, evaluasi risiko, penanganan risiko, monitoring, dan peninjauan, komunikasi dan konsultasi. Maka pada proses pelelangan, para stakeholder sudah mendapat gambaran mengenai risiko yang dihadapi, sehingga upaya mitigasi dapat ditingkatkan. Selain itu, diperlukan perencanaan yang lebih matang dengan melibatkan aspirasi masyrakat sejak dini untuk memudahkan dalam pembebasan lahan sebagai faktor risiko tertinggi.

\section{Saran}

Penelitian ini diperoleh beberapa saran sebagai berikut:

a. Pihak pemrakarsa pekerjaan SPAM regional selanjutnya perlu melakukan pembebasan lahan terlebih dahulu atau memastikan lahan yang akan dipakai untuk mengurangi timbulnya risiko terbesar pada pembebasan lahan.

b. Penelitian lanjutan dapat mengambil obyek penelitian pada pekerjaan SPAM regional lainnya untuk dapat dibandingkan hasil analisis risikonya serta dapat diambil kesimpulan mengenai manajemen risiko pada SPAM regional dari persepsi para stakeholder secara lebih komprehensif.

c. Penelitian lanjutan dapat dilakukan memperluas stakeholder lebih luas meliputi analisis risiko dari persepsi masyarakat terkena dampak, sub kontraktor, dan dari pihak perencana.

\section{Daftar Pustaka}

Anonim, 2005. Peraturan Pemerintah Republik Indonesia Nomor 16 Tahun 2005 tentang Pengembangan Sistem Penyediaan Air Minum.

Departemen Pekerjaan Umum, 2005. Pedoman Analisis Risiko Investasi Jalan Tol (Pd T-01-2005B).

Balai Besar Wilayah Sungai Pemali Juana, 2011. Booklet Pembangunan Jaringan Air Baku Kawasan Bregas (Banyumudal Serang Yamansari).

Balai Besar Wilayah Sungai Pemali Juana, 2012. Booklet Pembangunan Jaringan Air Baku Kawasan Bregas II (Tuk Suci).

Ciptakaru, 2011. Booklet SPAM Regional Jawa Tengah.

Harahap, Kaje, 2013. Analisa Risiko Pada Proyek Pembangunan Jalan Tol Nusa Dua - Ngurah RaiBenoa, Bali, Tugas Akhir, Fakultas Teknik Sipil dan Perencanaan, Institut Teknologi Sepuluh November, Surabaya.

Hillson, D. A., 2002. Use a Risk Break Down Structure (RBS) to Understand Your Risks, San Antonio, Texas, USA. 
Istijono, Bambang, 2014. Lahan Menjadi Faktor Penghambat dalam Pelaksanaan Pembangunan Untuk Kepentingan Umum, Universitas Andalas.

Nurdiana, Asri, 2011. Aplikasi Manajemen Risiko dari Persepsi Para Stakeholders (Studi Kasus Proyek Pembangunan Jalan Tol Semarang-Solo Seksi I Ruas Tembalang-Gedawang), Magister Teknik Sipil Universitas Diponegoro, Semarang.

Project Management Institute, 2004. A Guide to the Project Management Body of Knowledge (PMBOK Guide).

Santoso, Rudy, 2004. Tingkat Kepentingan dan Alokasi Risiko pada Proyek Konstruksi Thesis (Program Pascasarjana MTS Manajemen Konstruksi), Universitas Kristen Petra Surabaya.
Soemarmo, 2007. Risiko Penggunaan Lahan dan Analisisnya, Laboratorium PPJP FPUB.

Sonhaji, 2011. Manajemen Risiko dalam Proyek Jalan Tol, Diskusi Panel Manajemen Risiko Jalan Tol di Teknik Sipil Undip 2 Mei 2011.

Sutrisno, 1991. Teknologi Penyediaan Air Bersih, PT. Rineka Cipta, Jakarta.

Zhi, He, 1995. Risk Management for Overseas Construction Projects, International Journal of Project Management, Volume 13, Issue 4 Pages 231-237. 